\title{
Åpen kunnskap
}

Desember 2010. Det anerkjente fagfellevurderte tidsskriftet Science nettpubliserer det de tror er en revolusjonerende studie. NASA-forskeren Felisa Wolfe-Simon og medarbeidere har oppdaget en bakterie som kan vokse på arsenikk istedenfor fosfor (1). Funnet kan være avgjørende i jakten på liv på andre planeter. NASA har innkalt til pressekonferanse for å presentere de oppsiktsvekkende funnene (2). Responsen blir imidlertid ikke den NASA og Science har sett for seg.

Ganske umiddelbart møter studien kritikk fra fagfeller i sosiale medier. Man tviler på både resultatene og metoden. Implisitt i kritikken ligger det at fagfellevurderingen har vært for dårlig. I fremste linje blant kritikerne står mikrobiologen og bloggeren Rose Redfield fra University of British Columbia i Vancouver. Redfield er aktivist innen open science-bevegelsen (åpen vitenskap). Hun replikerer studien «for åpen scene» gjennom fortløpende å blogge om forsøkene og funnene hun gjør (3).

Kritikken når også spaltene i Science, og i juni 2011 publiserer redaktøren en kort kommentar sammen med alle leserbrevene som er kommet (4). Wolfe-Simon får siste ord. Artikkelen blir ikke trukket tilbake, men redaktøren påpeker at på tross av Wolfe-Simons respons er det fortsatt uløste spørsmål og at dette kun er starten på en lengre prosess. Rose Redfield blir i desember 2011 av Nature utpekt som en av årets ti mest betydningsfulle innen naturvitenskap (5). Høsten 2011 var hun en av hovedforedragsholderne på den internasjonale konferansen Science Online i London og ble mottatt som en rockestjerne. En av grunnpilarene i vitenskapelig publisering, fagfellevurdering, er blitt grundig utfordret. Av en blogger. Saken er bare ett av flere eksempler på hvordan det nå foretas viktig vurdering av vitenskapelige artikler i sosiale medier - etter publisering.

Den dugnadsbaserte ordningen med fagfellevurdering kritiseres hyppig av vitenskapsbloggere for å være et forsinkende ledd. Forskningsresultatene er utdatert før de blir publisert. Synspunktet er også fremført i Aftenposten av Petter Gottschalk, professor ved Handelshøyskolen BI. Diskusjonen om åpenhet og effektivitet i fagfellevurdering er ikke ny og har flere ganger vært berørt i våre spalter $(6,7)$. Nå fører tempoet i den teknologiske utviklingen og forkjemperne for åpen vitenskap til at diskusjon blir til utprøving.

Open science-bevegelsen mener modellen med lukkede prosesser frem til publisering i tradisjonelle tidsskrifter må fornyes. De ønsker åpenhet $\mathrm{i}$ alle ledd fra innsamling av data til fagfellevurdering og publisering (8). Via Internett er det enkelt å samle inn data gjennom f.eks. spørreundersøkelser og å gi andre fortløpende tilgang til dem. Hvem som helst kan publisere i blogger, der det lett kan kommenteres. Innspill fra fagfeller og såkalt kollektiv intelligens kan gjøre forskningen bedre gjennom hele prosessen. Det handler altså om mer enn fri tilgang til selve artikkelen. Vi ser den samme tendensen innen journalistikken. Leserne bidrar i datainnsamlingen og historiefortellingen, og bakgrunnsinformasjon gjøres tilgjengelig for leserne på nett i åpen journalistikk-prosjekter (open journalism). Kvalitetsavisen The Guardian er en av eksponentene for dette (9).

I Tidsskriftet deltar vi i utprøvningen av de nye mulighetene teknologien gir. I mai 2012 tok det tradisjonelle brevet til redaktøren endelig steget inn i de sosiale medienes tidsalder da vi innførte kommentarfelt i nettutgaven. Diskusjonen får større verdi når den skjer i tilknytning til indeksartikkelen. Nettversjonen av artikkelen er arkivversjonen, og alle synspunkter i responsfeltet lagres sammen med artikkelen.

I tråd med filosofien om åpen vitenskap har flere nettbaserte tidsskrifter en betydelig lavere terskel for godkjenning enn vi har. Men der refusjonsraten er lav eller forskningen fortløpende rapporteres i en blogg, er kravet til faglig diskusjon og vurdering i etterkant høyt. $\AA$ overlate all vurdering til etter publisering er en tvilsom strategi når vi vet at særlig medisinske tidsskrifter leses av flere enn eksperter og fagfeller. Artiklene blir utgangspunkt for medieoppslag og viral spredning i sosiale medier uten at det stilles kritiske spørsmål.

I juli 2012 ble en artikkel der Redfield og medarbeidere har replikert den opprinnelige arsenikkstudien publisert i Science (10).

Blogging under forskningsprosessen var ikke til hinder. Åpenhet og vurdering før publisering ble et supplement til tradisjonell fagfellevurdering og redaksjonell tilrettelegging. Vi er midt $i$ en tid der tradisjonelle måter å publisere på utfordres av både teknologi og åpenhetsfilosofi. Forskere og tidsskriftutgivere kan være passive tilskuere eller selv aktivt utnytte og sette premisser for den nye teknologien.

\section{Litteratur}

1. Wolfe-Simon F, Switzer Blum J, Kulp TR et al. A bacterium that can grow by using arsenic instead of phosphorus. Science 2011; 332: 1163-6. E-publisert 2.12.2010.

2. Pressemelding fra NASA 2.12.2010. www nasa.gov/home/hqnews/2010/dec/ HQ 10-320 Toxic Life.html (22.3.2013)

3. Rose Redfields blogg. http://rrresearch.fieldofscience.com/ (22.3.2013).

4. Alberts B. Editor's note. Science 2011; 332. doi:10.1126/science.1208877. E-publisert 27.5.2011.

5. Butler D, Callaway E, Hayden EC et al. 365 days: Nature's 10. Nature 2011; 480: 437- 45

6. Aavitsland P. Kritikk uten hemninger. Tidsskr Nor Legeforen 2008; 128: 1377

7. Bjørheim J, Frich JC, Gjersvik P et al. Tidsskriftet, ekstern fagvurdering og medisinsk publisering. Tidsskr Nor Lægeforen 2006; 126: $20-3$.

8. Gezelter D. What, exactly, is open science? The OpenScience Project-blogg. www.openscience. org/blog/? $=269$ (22.3.2013)

9. Rusbridger A. The Guardian: a world of news at your fingertips. Inside The Guardian blogg. www.guardian.co.uk/help/insideguardian/2012/feb/29/openjournalism-at-the-guardian (22.3.2013).

10. Reaves ML, Sinha S, Rabinowitz JD et al. Absence of detectable arsenate in DNA from arsenate-grown GFAJ-1 cells. Science 2012; 337: 470-3 